\title{
Similar effects of bottom trawling and natural disturbance on composition and function of benthic communities across habitats
}

van Denderen, Pieter Daniël; Bolam, S.G.; Hiddink, J.G.; Jennings, S.; Kenny, A.; Rijnsdorp, A.D.; van Kooten, $\mathrm{T}$.

Published in:

Marine Ecology - Progress Series

Link to article, DOI:

$10.3354 /$ meps 11550

Publication date:

2015

Document Version

Publisher's PDF, also known as Version of record

Link back to DTU Orbit

Citation $(A P A)$ :

van Denderen, P. D., Bolam, S. G., Hiddink, J. G., Jennings, S., Kenny, A., Rijnsdorp, A. D., \& van Kooten, T. (2015). Similar effects of bottom trawling and natural disturbance on composition and function of benthic communities across habitats. Marine Ecology - Progress Series, 541, 31-43. https://doi.org/10.3354/meps 11550

\section{General rights}

Copyright and moral rights for the publications made accessible in the public portal are retained by the authors and/or other copyright owners and it is a condition of accessing publications that users recognise and abide by the legal requirements associated with these rights.

- Users may download and print one copy of any publication from the public portal for the purpose of private study or research.

- You may not further distribute the material or use it for any profit-making activity or commercial gain

- You may freely distribute the URL identifying the publication in the public portal 


\title{
Similar effects of bottom trawling and natural disturbance on composition and function of benthic communities across habitats
}

\author{
P. Daniël van Denderen ${ }^{1,2,5, *}$, Stefan G. Bolam ${ }^{3}$, Jan Geert Hiddink ${ }^{4}$, \\ Simon Jennings ${ }^{3}$, Andrew Kenny ${ }^{3}$, Adriaan D. Rijnsdorp ${ }^{1,2}$, Tobias van Kooten ${ }^{1}$ \\ ${ }^{1}$ Wageningen Institute for Marine Resources and Ecosystem Studies (IMARES), PO Box 68, 1970 AB IJmuiden, \\ The Netherlands \\ ${ }^{2}$ Aquaculture and Fisheries, Wageningen University, PO Box 338, 6700 AH Wageningen, The Netherlands \\ ${ }^{3}$ Centre for Environment, Fisheries and Aquaculture Science (CEFAS), Lowestoft Laboratory, Pakefield Road, Lowestoft, \\ Suffolk NR33 0HT, UK \\ ${ }^{4}$ School of Ocean Sciences, Bangor University, Menai Bridge, Anglesey LL59 5AB, UK \\ ${ }^{5}$ Present address: National Institute of Aquatic Resources, Technical University of Denmark, Charlottenlund Castle, \\ 2920 Charlottenlund, Denmark
}

\begin{abstract}
Bottom trawl fishing has widespread impacts on benthic habitats and communities. The benthic response to trawling seems to be smaller or absent in areas exposed to high natural disturbance, leading to the hypothesis that natural and trawl disturbance affect benthic communities in a similar way. However, systematic tests of this hypothesis at large spatial scales and with data from sites spanning a large range of natural disturbance do not exist. Here, we examine the effects of trawl and natural (tidal-bed shear stress) disturbance on benthic communities over gradients of commercial bottom trawling effort in 8 areas in the North and Irish Seas. Using a traitbased approach, that classified species by life-history strategies or by characteristics that provide a proxy for their role in community function, we found support for the hypothesis that trawl and natural disturbance affect benthic communities in similar ways. Both sources of disturbance caused declines in long-living, hard-bodied (exoskeleton) and suspension-feeding organisms. Given these similar impacts, there was no detectable trawling effect on communities exposed to high natural disturbance. Conversely, in 3 out of 5 areas with low bed shear stress, responses to trawling were detected and resulted in community compositions comparable with those in areas subject to high natural disturbance, with communities being composed of either small-sized, deposit-feeding animals or mobile scavengers and predators. The findings highlight that knowledge of the interacting effects of trawl and natural disturbance will help to identify areas that are more or less resilient to trawling and support the development of management plans that account for the environmental effects of fishing
\end{abstract}

KEY WORDS: Bottom trawling · Benthic community · Biological trait approach · Bed shear stress · Ecosystem function $\cdot$ Disturbance $\cdot$ Beam trawling $\cdot$ Otter trawling

Resale or republication not permitted without written consent of the publisher

\section{INTRODUCTION}

Bottom trawl fisheries account for around $23 \%$ of global fisheries yield (FAO 2009) and are among the most widespread sources of human disturbance affecting benthic communities in shallow shelf seas (Eastwood et al. 2007, Foden et al. 2011). The fishery physically disturbs the seabed by dragging the fishing gear over the seabed to catch bottom-dwelling fish and benthic invertebrates. This disturbance 
modifies benthic habitats and leads to mortality of benthic invertebrates in the path of the gear (Kaiser et al. 2002).

The effects of trawling vary markedly among benthic species (Collie et al. 2000a, Kaiser et al. 2006), as a result of their different vulnerability to a trawl pass (e.g. Bergman \& van Santbrink 2000) and different recovery rates following impact, varying from months to many years (e.g. Lambert et al. 2014). Generally, studies have found that long-living, sessile and suspension-feeding organisms show the greatest declines in response to a given type and frequency of trawl disturbance (Tillin et al. 2006, de Juan et al. 2007, Kenchington et al. 2007), while opportunistic species, e.g. short-living polychaetes, are less affected (Kaiser et al. 2006).

The response of a benthic community to trawling will also depend on the pre-fished composition of the community (Kaiser et al. 2002). This composition is largely affected by the degree of natural disturbance, due to currents, waves or storms (Thistle 1981, Probert 1984). Natural disturbance may erode seabed sediment, cause resuspension of organic matter (Morris \& Howarth 1998) and may affect settlement of new recruits (Thistle 1981, Hunt \& Scheibling 1997). Such effects promote species that are adapted to natural disturbance; species that usually have opportunistic life-history strategies and may also be resistant to trawl disturbance (Jennings \& Kaiser 1998, Kaiser 1998). Indeed, changes in response to trawling seem to be smaller or undetectable in communities exposed to high natural disturbance (e.g. Kaiser \& Spencer 1996, Collie et al. 2000b, Tillin et al. 2006), leading to the hypothesis that natural and trawl disturbance affect benthic communities in a similar way (Kaiser 1998).

Support for this hypothesis can be inferred from Hiddink et al.'s (2006) study of the relationships between trawling intensity, benthic biomass and richness in 4 areas in the North Sea subject to varying levels of natural disturbance. However, systematic tests of the hypothesis in many areas with data spanning many levels of natural disturbance have not been conducted. One approach that allows the hypothesis to be tested in a systematic way in many areas where communities will differ in species composition is to group benthic species in each area by traits that provide proxies for their role in community function (for review see Pearson 2001, Bremner 2008). Trait-based approaches have already been used successfully to describe the impacts of bottom trawling on benthic communities (Bremner et al. 2003, Tillin et al. 2006, de Juan et al. 2007, Kenchington et al. 2007, Bolam et al. 2014).

Here, we use a biological trait approach to assess the effects of trawling and natural disturbance on benthic community composition and function. We combine data from 8 studies of trawling impacts at different sites throughout the North and Irish Seas. Our results confirm the hypothesis that bottom trawling and natural disturbance have comparable effects on benthic communities. These findings are expected to be relevant to management in that they may help to identify areas that are more or less resilient to trawl impact (sensu Diesing et al. 2013) and support the development of management plans that take into account the environmental effects of fishing.

\section{METHODS}

\section{Study area}

The effects of trawling were assessed in 8 areas where soft-sediment benthic communities were sampled across a gradient in trawling disturbance. Of these, 7 were located in the North Sea and 1 in the Irish Sea (Fig. 1). Sampling sites were selected to cover the trawling intensity gradient in each area, while keeping the environmental conditions as homogenous as possible (Table 1). The 8 areas differed in terms of habitat type (expressed as depth, sediment type and primary productivity) and as such in their degree of natural disturbance, as predicted by calculating the force per unit area exerted on the seabed by the tidal currents (i.e. tidal-bed shear stress). Areas were categorised and named on the basis of their mean tidal-bed shear stress, assigning A to the area with the lowest shear stress and $\mathrm{H}$ to the highest. For 6 areas (A, B, D, E, F, G), homogeneity of other habitat characteristics was maximised by limiting the distance between sampling sites in the area and by selecting sites with similar habitat conditions (based on depth and sediment maps and/or habitat information from previous field studies; see Table 1: Ref. to area). For the 2 other areas $(\mathrm{C}, \mathrm{H})$, sampling sites were selected from monitoring sites in the Dutch Exclusive Economic Zone based on similarity of sediment grain size conditions, and so these covered a much larger area (Table 1: Ref. to area). Sample data from 4 areas (B, C, D, H) have been published previously (Table 1: Ref. to dataset), but have not been used to investigate benthic community composition and function. Temporal differences between areas, 


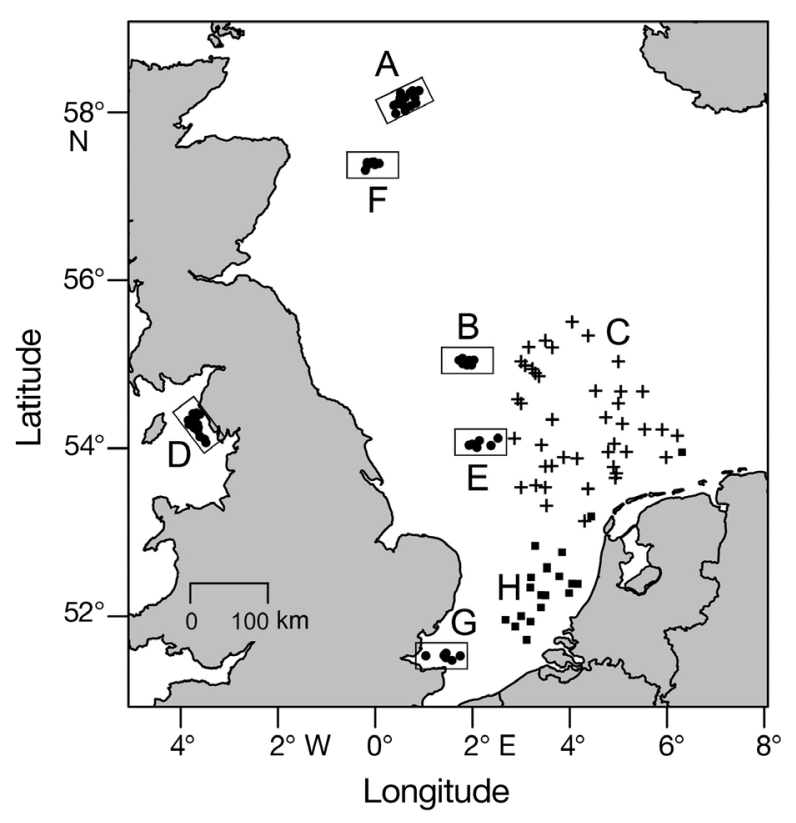

Fig. 1. The 8 different study areas (see Table 1 for area codes) and associated sampling sites

due to timing of sampling, were minimised as most of the selected areas were sampled between June and August (Table 1). In addition, we expected that temporal differences were of minor importance for explaining the variation in community composition due to the large differences in habitat conditions between areas.

\section{Benthic sampling and trait classification}

The number of benthic sampling sites ranged from 6 to 230 among areas, while the number of samples taken at each site ranged from 1 to 5 (Table 1). When there was more than 1 replicate per site, samples were pooled to provide an integrated description of the benthic community at each sampling site. The benthos was sampled using a $0.1 \mathrm{~m}^{2}$ Day grab (Areas $A$ and D), a $0.1 \mathrm{~m}^{2}$ Hamon grab (Areas $B$ and F) or a $0.078 \mathrm{~m}^{2}$ Reineck box corer (Areas C, E, G and H). The different gears have a different penetration depth and sample a different surface area but they were selected because no single gear can operate effectively on all substrate types. However, all these gears do sample the smaller epi- and infaunal component of the benthic fauna and provide a quantitative estimate of their abundance and biomass (Eleftheriou \& Moore 2005). Samples from all areas were sieved over a $1 \mathrm{~mm}$ mesh sieve and biota were identified to the lowest taxonomic level possible. Biomass

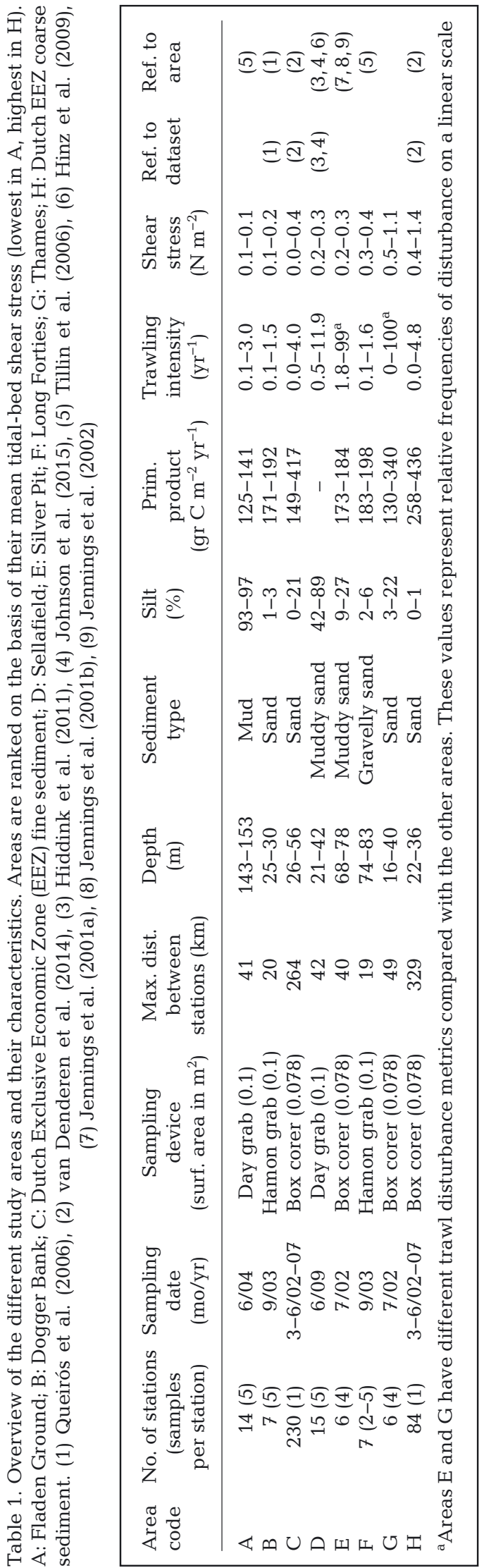


per taxonomic group was estimated in grams ashfree dry weight (Areas $\mathrm{C}$ and $\mathrm{H}$ ) or wet weight (other areas). Some large and low-density individuals are not effectively sampled by the gears and were removed from the data. We removed individuals when their biomass was larger than the mean biomass (excluding these individuals) of all samples in the area. A total of 29 large individuals were removed from the entire data set (e.g. a masked crab Corystes cassivelaunus, a common otter shell Lutraria lutraria and a heart urchin Echinocardium cordatum), representing $<0.001 \%$ of all individuals and $17.8 \%$ of the total biomass.

Besides these few large individuals, most areas had 1 or 2 genera (heart urchins from the genera Echinocardium in 4 areas and Brissopsis in 2 areas, and a razor clam Ensis and a brittle star Amphiura in 1 area) that dominated the biomass of the sampled fauna ( 28 to $74 \%$ of total biomass). Fishing effects on these dominant taxa were expected to overshadow the wider community responses that are the focus of this study (see Supplement 1 at www.int-res. com/articles/suppl/m541p031_supp.pdf) and so we assessed the responses of these taxa to trawling separately.

We used a suite of 10 biological traits to describe changes in the function and resilience of benthic communities in response to bottom trawling and shear stress. In total, trait information was obtained for 222 different genera and 59 unique higher taxonomic groupings (mostly 'family') for which biomass data were available (Bolam et al. 2014). Each trait was subdivided into multiple modalities (Table 2). For each genera-trait combination, a single trait modality was assigned a score of 1 when the genus showed total affinity for that particular modality. When the genus could not be assigned unequivocally to a single trait modality, multiple modalities were assigned fractional scores that summed to 1 , depending on the affinity of that genus for that modality (fuzzy coding, see Chevene et al. 1994). When genera could not be identified, traits were defined for higher taxonomic levels. From this genera-by-trait matrix (including the higher taxonomic levels), we calculated a table of sampling sites by biomass-weighted modalities. This was done for each sampling site by multiplying the total biomass per taxonomic grouping by the score for each trait modality. These were summed by modality to produce a biomass-weighted trait modality table for all sampling sites (Tillin et al. 2006, Bolam et al. 2014). Four taxonomic groups, representing $0.5 \%$ of the biomass, were excluded from the analysis as no trait data were available.

\section{Trawl disturbance, natural disturbance and habitat conditions}

To assess the intensity of trawling and natural disturbance, and to describe environmental factors that may affect community composition, we combined depth and sediment data collected during the benthic sampling with estimates of trawl disturbance, tidal-bed shear stress and primary production for the same sites.

Type of sediment, silt percentage and depth were site-specific data collected during the benthic sampling. The distinction in sediment type was based on the classification diagram of Folk (Folk 1954). Silt percentage was obtained from particle size analysis. Except for Areas $\mathrm{C}$ and $\mathrm{H}$, depth was directly measured at the benthic sampling location. Depths for Areas $\mathrm{C}$ and $\mathrm{H}$ were extracted from bathymetric data (see van Denderen et al. 2014).

Table 2. Benthic traits, their modalities and corresponding abbreviations

\begin{tabular}{|c|c|c|}
\hline Traits & Modalities & Abbreviation \\
\hline Size $(\mathrm{mm})$ & $\begin{array}{l}<21 \\
21-100 \\
101-200 \\
>200\end{array}$ & $\begin{array}{l}\mathrm{S}<21 \\
\mathrm{~S} 21-100 \\
\mathrm{~S} 101-200 \\
\mathrm{~S}>200\end{array}$ \\
\hline Morphology & $\begin{array}{l}\text { Soft } \\
\text { Exoskeleton }\end{array}$ & $\begin{array}{l}\text { M_soft } \\
\text { M_exo }\end{array}$ \\
\hline Longevity (yr) & $\begin{array}{l}<3 \\
3-10 \\
>10\end{array}$ & $\begin{array}{l}\mathrm{L}<3 \\
\mathrm{~L} 3-10 \\
\mathrm{~L}>10\end{array}$ \\
\hline $\begin{array}{l}\text { Larval develop- } \\
\text { ment }\end{array}$ & $\begin{array}{l}\text { Planktotrophic } \\
\text { Lecithotrophic/direct }\end{array}$ & $\begin{array}{l}\text { LD_plank } \\
\text { LD_le/di }\end{array}$ \\
\hline Egg development & $\begin{array}{l}\text { Pelagic } \\
\text { Benthic } \\
\text { Brooded }\end{array}$ & $\begin{array}{l}\text { ED_pela } \\
\text { ED_bent } \\
\text { ED_brood }\end{array}$ \\
\hline Living habit & $\begin{array}{l}\text { Tube-dwelling } \\
\text { Burrow-dwelling } \\
\text { Free-living }\end{array}$ & $\begin{array}{l}\text { LH_tube } \\
\text { LH_burrow } \\
\text { LH_free }\end{array}$ \\
\hline Sediment position & $\begin{array}{l}\text { Surface } \\
\text { Shallow }(0-5 \mathrm{~cm}) \\
\text { Mid-depth }(6-10 \mathrm{~cm}) \\
\text { Deep }(>10 \mathrm{~cm})\end{array}$ & $\begin{array}{l}\text { SP_surf } \\
\text { SP0-5 } \\
\text { SP6-10 } \\
\text { SP>10 }\end{array}$ \\
\hline Feeding type & $\begin{array}{l}\text { Suspension-feeder } \\
\text { Deposit-feeder } \\
\text { Scavenger } \\
\text { Predator }\end{array}$ & $\begin{array}{l}\text { F_susp } \\
\text { F_dep } \\
\text { F_scav } \\
\text { F_pred }\end{array}$ \\
\hline Mobility & $\begin{array}{l}\text { Sessile } \\
\text { Swimmer/crawler } \\
\text { Burrower }\end{array}$ & $\begin{array}{l}\text { M_sessile } \\
\text { M_swi/cr } \\
\text { M_bur }\end{array}$ \\
\hline $\begin{array}{l}\text { Bioturbation } \\
\text { activity }\end{array}$ & $\begin{array}{l}\text { Diffusive mixing } \\
\text { Surface deposition } \\
\text { Others }\end{array}$ & $\begin{array}{l}\text { BT_dif } \\
\text { BT_dep } \\
\text { BT_others }\end{array}$ \\
\hline
\end{tabular}


Estimates of the amount of trawl disturbance were based on quantifying the fishing activities of both beam and/or otter trawls. Both types of trawling disturb seabed sediment and impact benthic communities (Kaiser et al. 2006). Trawl disturbance for Areas A, B, C, D, F and $\mathrm{H}$ was estimated using satellite Vessel Monitoring System (VMS) data and expressed as the ratio between the area of the site that is trawled each year and the total area of the site (the data sources and exact calculations of trawl disturbance have been explained in previous articles, see Table 1: Ref. to area). Trawl disturbance for Areas E and $G$ was estimated from aerial survey data collected by fisheries inspection services (Jennings et al. 2001a).

Tidal-bed shear stress was estimated using a 2dimensional hydrographic model. This model predicts shear stress (the force per unit area exerted on the seabed by the tidal currents: $\mathrm{N} \mathrm{m}^{-2}$ ) per sampled station on a $1 / 8^{\circ}$ longitude by $1 / 12^{\circ}$ latitude spatial scale. The shear stress calculations are explained in more detail in Hiddink et al. (2006).

Primary productivity was obtained through predictions from GETM-ERSEM (General Estuarine Transport Model-European Regional Seas Ecosystem Model) (Baretta et al. 1995). GETM-ERSEM describes the temporal and spatial patterns of the biogeochemistry of the water column and sediment using 2 coupled hydrodynamic models. These models predicted total production of new phytoplankton biomass for each year $\left(\mathrm{g} \mathrm{C} \mathrm{m}^{-2} \mathrm{yr}^{-1}\right)$ on a $10 \times 10 \mathrm{~km}$ spatial scale. Total production was estimated for each sampling site, except for Area D, over a period of $1 \mathrm{yr}$ prior to the sampling date. These modelled productivities approximate measured primary productivity (Ebenhoh et al. 1997).

\section{Statistical analysis}

We first analysed the effect of trawling on trait composition for all areas together by aggregating the sampling sites for each area into 'low', 'intermediate' and 'high' trawl disturbance treatments. We then analysed the effects of trawling on trait composition for each area individually using the gradient in trawling disturbance rather than the 3 categories. Finally, we analysed the effects of trawling for the few dominant genera separately (see Supplement 1).

For the first analysis, we examined the proportion of biomass per modality within trait categories, as this allowed us to compare areas that may vary greatly in their total biomass and that were sampled with different gears. We defined low trawl disturbance as an intensity $\leq 0.2 \mathrm{yr}^{-1}$ as this means that there will be, on average, a trawl pass once every $5 \mathrm{yr}$. We defined intermediate trawl disturbance at an intensity of $>0.2$ to $\leq 0.5 \mathrm{yr}^{-1}$. All other sampling sites were grouped into the high trawl disturbance group. Since trawl disturbance of both Areas $\mathrm{E}$ and $\mathrm{G}$ was based on different metrics, we rescaled the overflight effort data of these areas to trawling intensity based on the maximum trawling intensity estimates found in Area E by Hiddink et al. (2006). Differences in trait composition between areas and 'low', 'intermediate' and 'high' trawl disturbance treatments were examined with a correspondence analysis that included bootstrapped p-values from a hierarchical cluster analysis (Suzuki \& Shimodaira 2006).

In the second analysis, we described the effects of trawling on trait composition for each area separately using the trawling intensity gradient and biomass per modality (instead of proportion of biomass per modality). This was done with a redundancy analysis where we used the trawling intensity gradient as a predictor variable. With only 1 predictor variable present, the redundancy analysis is the multivariate analogue of linear regression (Legendre \& Legendre 2012) and may be used to determine which trait modalities are positively or negatively correlated to trawl disturbance. The approach will show whether the observed shifts in response to trawling are relative, indicating that some organisms are less (negatively) affected by trawl disturbance than others, or absolute, indicating an increase in the biomass abundance of certain trait modalities at high trawl disturbance. The redundancy analysis assumes there is a linear relationship between the predictor variable and its response. For that reason trawl disturbance was log transformed as we expected the trait modalities sensitive to trawl disturbance to decline exponentially (Tillin et al. 2006, Hiddink et al. 2011). Whether trawl disturbance had a significant effect on community composition for each area was tested using a permutation test. Since sampling sites in Areas $\mathrm{C}$ and $\mathrm{H}$ covered a large spatial scale and were only selected on the basis of similar sediment grain size conditions, the effects of trawling in these 2 areas were examined using a partial redundancy analysis that controlled for the environmental conditions. All multivariate analyses were done using the package 'vegan' in program R (Oksanen et al. 2013). 
Finally, we analysed the effects of trawling on a few dominant genera separately as their responses overshadow the community response to trawling (Fig. S1 in Supplement 1). This was achieved by investigating the relationship between trawling intensity and biomass which was $\log (x+1)$ transformed to improve model fit.

\section{RESULTS}

\section{Effects of trawling on trait composition for all areas combined}

When sites were grouped into 'low', 'intermediate' and 'high' trawl disturbance treatments, the analysis of trawling effects on trait composition showed that high trawling disturbance led to trait compositions similar to those in areas subject to high shear stress. The correspondence analysis based on trait composition produced 5 different clusters (Fig. 2). Five of the areas $(\mathrm{A}, \mathrm{C}, \mathrm{F}, \mathrm{G}$ and $\mathrm{H})$ remained within the same cluster at low, intermediate and high trawl disturbance, and this suggests that their trait composition does not change with trawling. The other 3 areas (B, D and E) had a similar trait composition at low and/or intermediate trawling (Figs. 2a \& 3, Area D had no low trawl disturbance treatment), which is most associated with the modalities exoskeleton, a maximum longevity of $>10 \mathrm{yr}$ and suspension-feeder (Fig. 2b). Trawling caused significant changes in trait composition in Areas B, D and E, and these changes led to community compositions comparable with those in areas subject to high shear stress (Figs. $2 \& 4$ ). Thus, Area B, at intermediate and high trawl disturbance, and $\mathrm{D}$, at high trawl disturbance, clustered with Area $\mathrm{H}$. This group is most associated with the modalities swimmer/crawler, scavenger, predator and diffusive mixing activity. Area E clustered, at high trawl disturbance, with Areas F and G (Fig. 2a), and this group is most strongly associated with the modalities small-sized $(<21 \mathrm{~mm})$, a maximum longevity of $<3 \mathrm{yr}$, surface-living, benthic or brood egg development, tube-dwelling and deposit-feeder.

No detectable effects of trawling were found in the area with the lowest shear stress (Area A) or in Area C. The trait composition for Area A, at low and high trawl disturbance, is most strongly associated with the modalities direct or lecithotrophic larval development, large-sized (>200 mm), a maximum longevity of $<3 \mathrm{yr}$, and soft-bodied (Figs. $2 \& 3$ ). Area C was not strongly associated with any specific trait modalities.
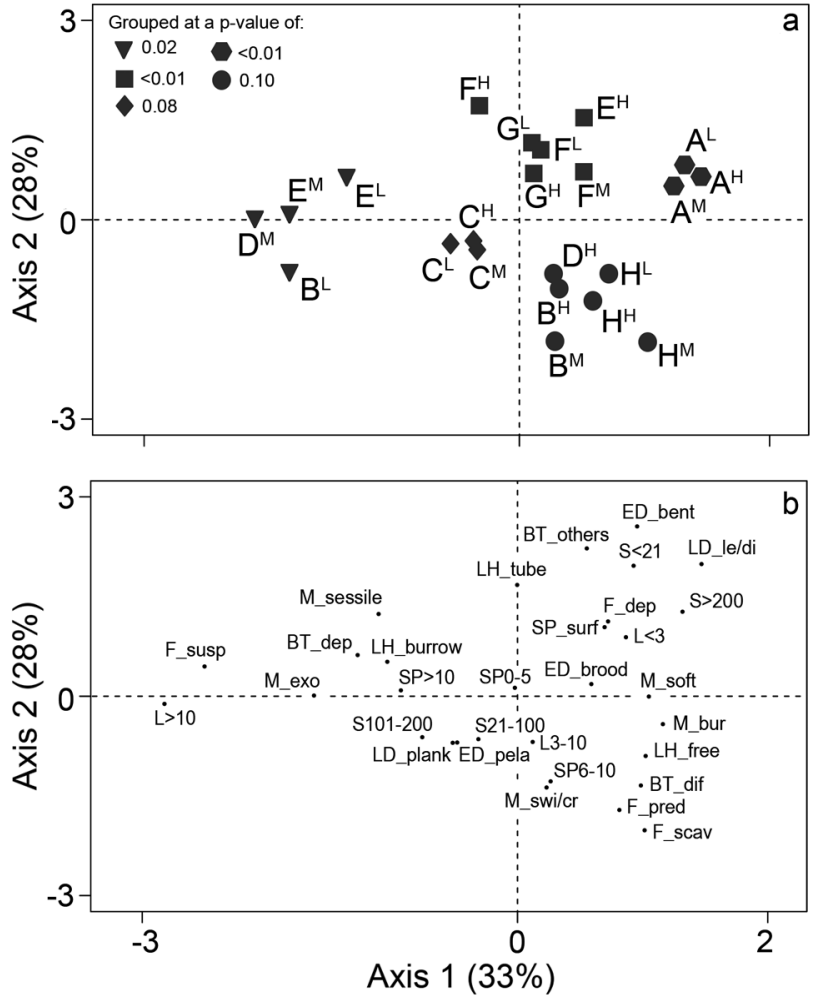

Fig. 2. Outcome of the correspondence analysis based on trait composition for (a) the different sampling areas, split into a 'low' $\left({ }^{\mathrm{L}}\right)$, 'intermediate' $\left({ }^{\mathrm{M}}\right)$ and 'high' $\left({ }^{\mathrm{H}}\right)$ trawl disturbance treatment (see Table 1 for area descriptions), and (b) trait modalities. The correspondence analysis shows 5 different clusters in (a), grouped at a p-value between $<0.01$ and 0.10 (represented by different symbols). The abbrevia tions in (b) correspond to the trait modalities in Table 2

\section{Effects of trawling on trait composition tested for each area separately}

The 3 areas that show shifts in trait composition (Areas B, D and E) were also significantly affected by trawling when they were treated independently (Fig. 5). Trawling explained $52 \%$ of the variation in trait composition in $\mathrm{B}, 63 \%$ in $\mathrm{D}$ and $55 \%$ in $\mathrm{E}$. A number of modalities were consistently and negatively correlated with trawl disturbance (Fig. 5) in all 3 areas. These were the modalities exoskeleton, sessile, suspension-feeder, planktotrophic larval development, pelagic egg development, burrowdwelling, positioned $0-5 \mathrm{~cm}$ in the sediment, surfacedeposition activity and a maximum longevity of 3-10 or $>10$ yr. A few abundant bivalve genera in these areas have all these modalities combined (such as Dosinia, Spisula, Acanthocardia, Ensis, Phaxas and Abra). 
(a) Maximum size $(\mathrm{mm})$

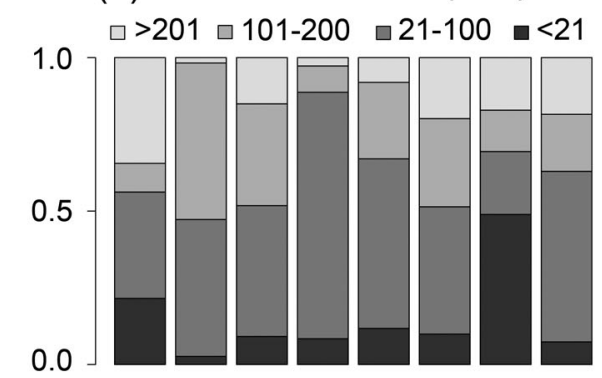

(d) Larval development

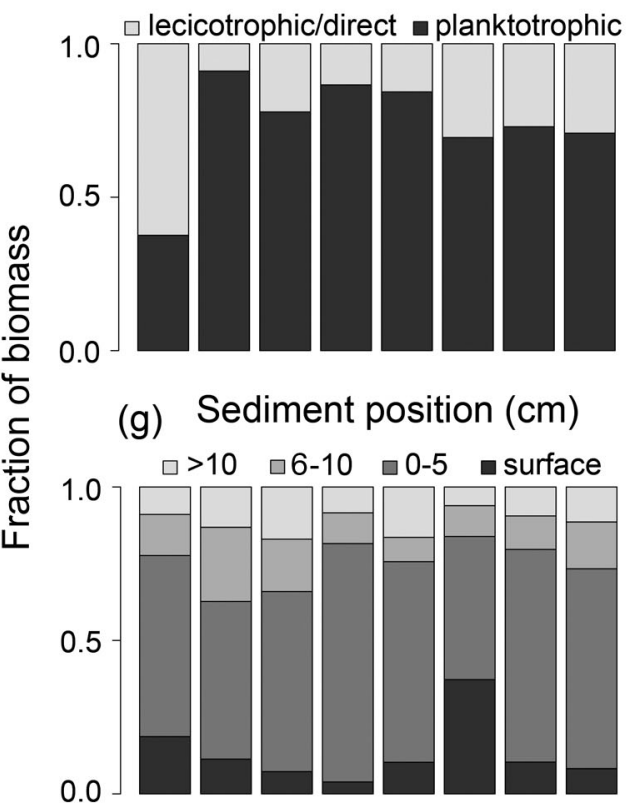

(j) Bioturbation activity

$\square$ others $\square$ deposition $\square$ diffusive mix.

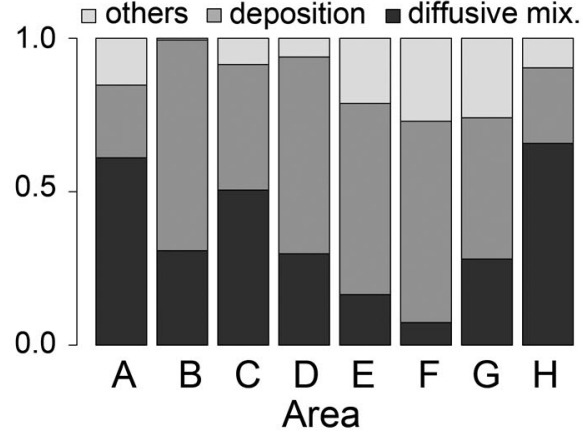

(b)

Morphology

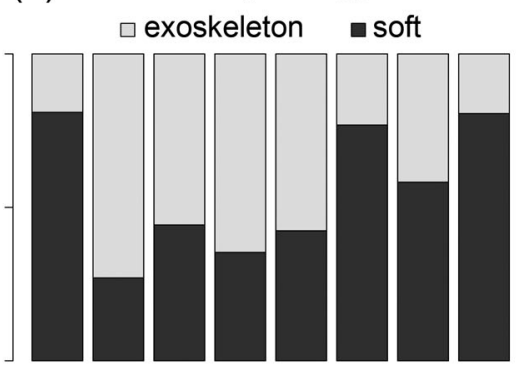

(e) Egg development

$\square$ brooded $\square$ benthic $\square$ pelagic

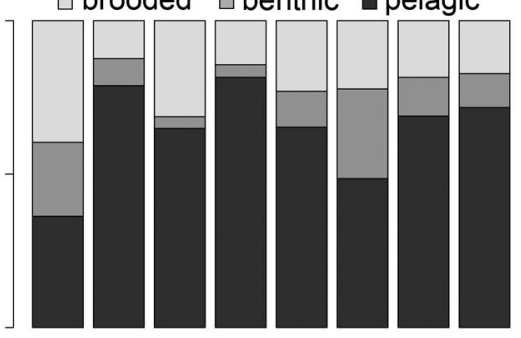

(h)

Feeding type

$\square$ predat. $\square$ scaven. $\square$ deposit $\square$ suspen.

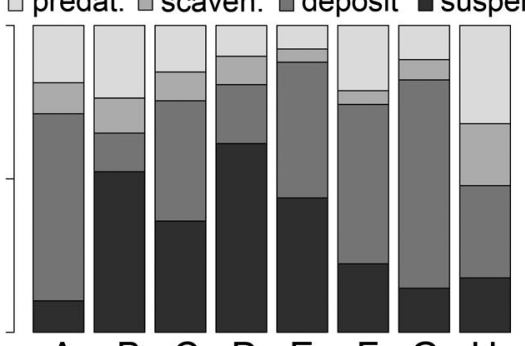

A B C D E F G H Area (c) Longevity (yr)

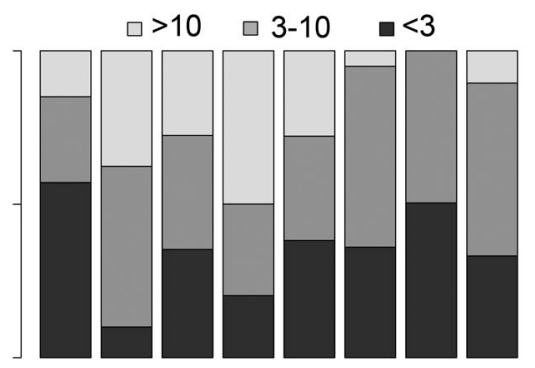

(f)

Living habitat

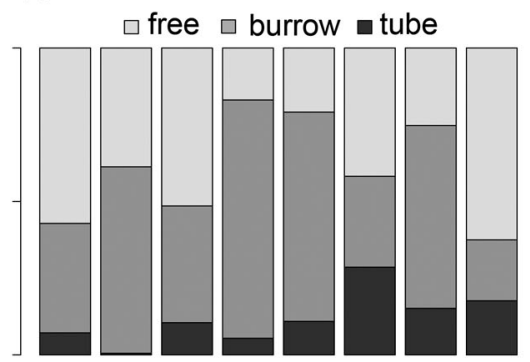

(i)

$\square$ burrower $\square$ swim/crawl $\square$ sessile

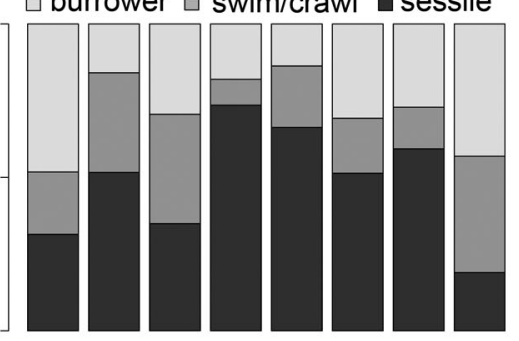

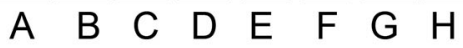
Area

Fig. 3. Overview of the differences in trait composition for 7 areas at 'low' trawl disturbance and for Area D at 'intermediate' trawl disturbance due to availability of data. Figure panels show fractions of biomass per modality for all traits. Outcome is based on the mean of the sampling stations (replicates are pooled). See Table 1 for area descriptions. Number of sampling stations (replicates) differ for each site: A: 2(5); B: 3(5); C: 92(1); D: 1(5); E: 1(4); F: 2(2 and 5); G: 3(4); H: 9(1)

Trawling in Areas B and D was also negatively correlated with all other trait modalities and this means that the shift in trait composition is only based on relative increases. In contrast, trawl disturbance in Area E was positively correlated with the modalities smallsized $(<21 \mathrm{~mm})$, direct or lecithotrophic larval devel- opment and the bioturbation activity 'other'. This indicates absolute increases in biomass of fauna with these modalities in response to trawling, but these effects were not significant when tested using univariate statistics (see Table S2 in Supplement 2 at www.int-res.com/articles/suppl/m541p031_supp.pdf). 
(a) Maximum size $(\mathrm{mm})$

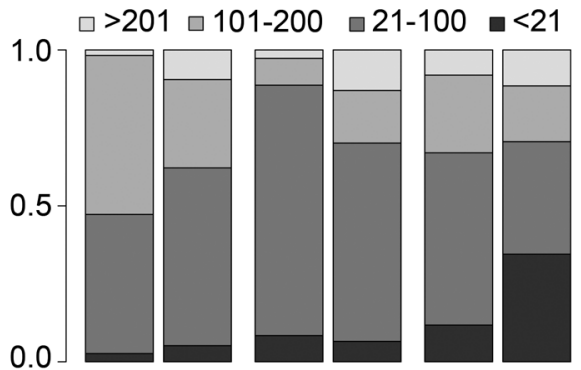

(d) Larval development

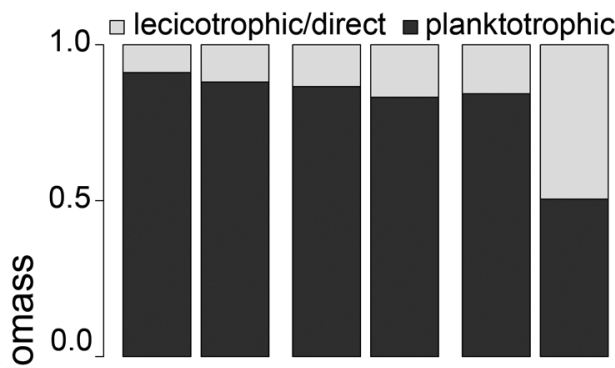

(g) Sediment position (cm)

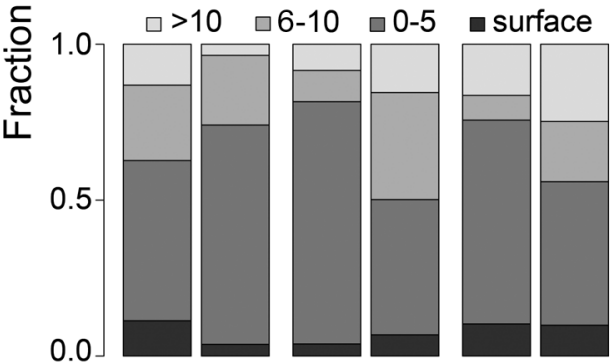

(j) Bioturbation activity

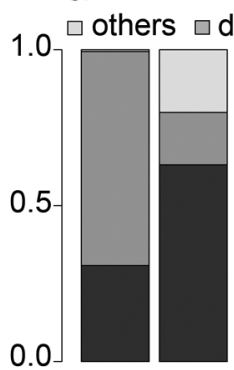

$B^{L} \quad B^{H}$

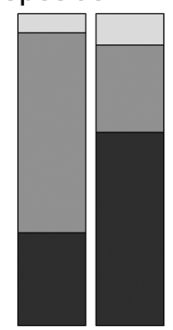

$D^{M} \quad D^{H}$

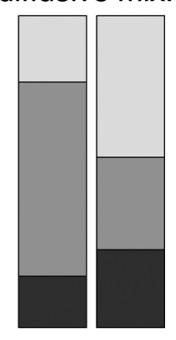

$E^{\mathrm{L}} \quad \mathrm{E}^{\mathrm{H}}$ (b)

Morphology $\square$ exoskeleton

n soft
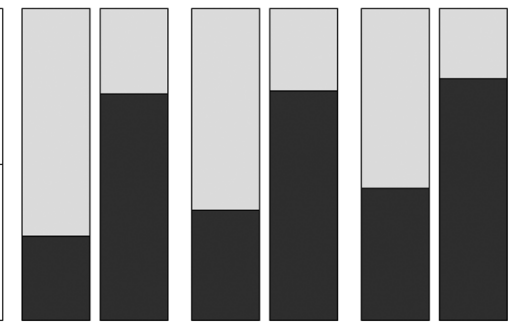

(e) Egg development

$\square$ brooded $\square$ benthic apelagic
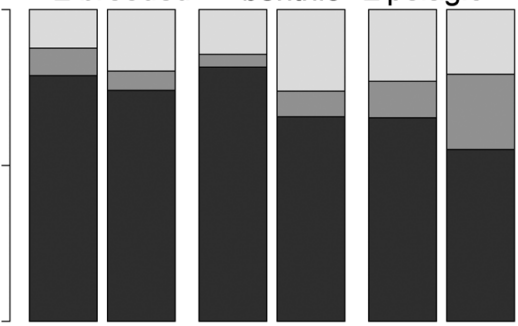

(h)

Feeding type

$\square$ predat. $\square$ scaven. $\square$ deposit $\square$ suspen.
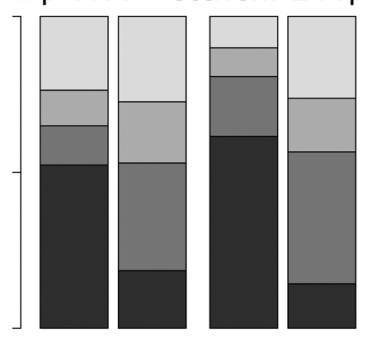

$B^{L} \quad B^{H}$

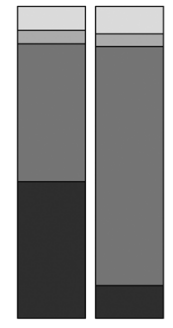

$E^{\mathrm{L}} \quad \mathrm{E}^{\mathrm{H}}$ (c) Longevity (yr)

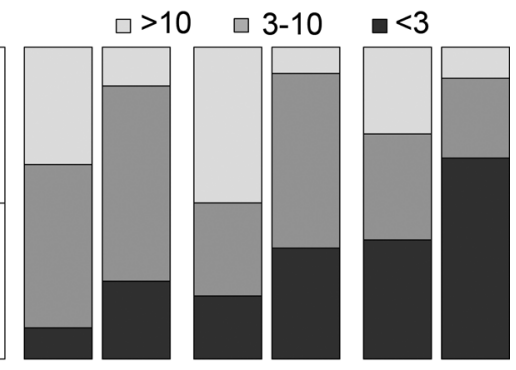

(f)

Living habitat

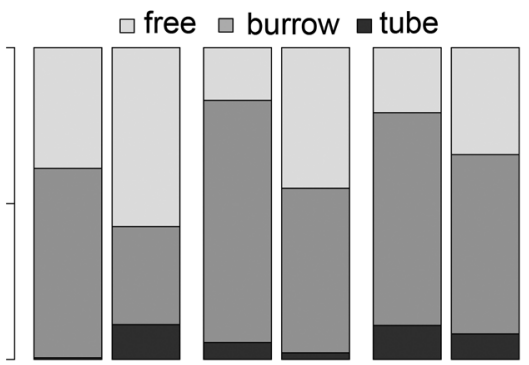

(i)

Mobility $\square$ burrower $\square$ swim/crawl $\square$ sessile
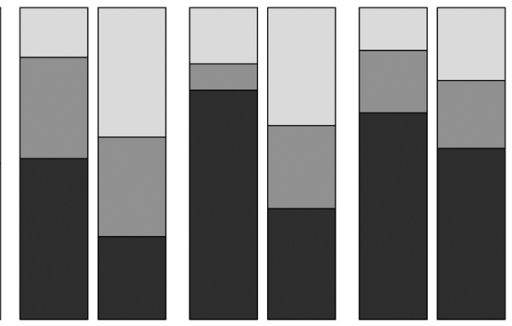

$B^{L} \quad B^{H} \quad D^{M} \quad D^{H} \quad E^{L} \quad E^{H}$

Fig. 4. Overview of the differences in trait composition between sampling sites exposed to 'low' $\left({ }^{\mathrm{L}}\right)\left(\right.$ 'intermediate' $\left[{ }^{\mathrm{M}}\right.$ ] for Area D), and 'high' $\left({ }^{\mathrm{H}}\right)$ trawl disturbance for the 3 different areas that show shifts in trait composition in response to trawling (Fig. 2). Figure panels show fractions of biomass per modality for the different traits. Outcome is based on the mean of the sampling sites (replicates are pooled). Number of sampling sites (replicates) differ for each area and trawl disturbance treatment: $\mathrm{B}^{\mathrm{L}}: 3(5) ; \mathrm{B}^{\mathrm{H}}: 2(5) ; \mathrm{D}^{\mathrm{M}}: 1(5) ; \mathrm{D}^{\mathrm{H}}: 14(5) ; \mathrm{E}^{\mathrm{L}}: 1(4) ; \mathrm{E}^{\mathrm{H}}: 3(4)$
No significant effects of trawl disturbance on trait composition were observed in the other areas (all $\mathrm{p}$-values in permutation tests > 0.24). Trawling explained only $9 \%$ of the variation in trait composition in $\mathrm{A}, 0.3 \%$ in $\mathrm{C}, 19.5 \%$ in $\mathrm{F}, 26 \%$ in $\mathrm{G}$ and $1.4 \%$ in $\mathrm{H}$.

\section{Effects of trawling on dominant genera}

Biomass in each study area was dominated by only 1 or 2 genera. The relationships between trawling intensity and log biomass of each of these dominant genera is shown in Table 3 . The biomass of the 
dominant genera in Area D, Amphiura and Echinocardium, was negatively related to trawl disturbance, while no significant effects of trawling were observed in the other dominant genera.

\section{DISCUSSION}

We found no effects of trawling on benthic invertebrate communities at locations with high natural disturbance (Areas F, G and H), while in 3 out of 5 areas with more stable natural conditions, clear shifts were observed in trait composition in relation to trawling disturbance (Areas B, D and E). In these areas, trawling resulted in community compositions comparable with those in areas subject to high natural disturbance. Hence, our results provide support for the hypothesis that trawl and natural disturbance affect benthic communities in similar ways. Both sources of disturbance cause declines in long-living, hardbodied (exoskeleton) and suspension-feeding animals and these effects are likely to affect community function.

The comparable effects of trawl and natural disturbance may help to identify areas that are particularly susceptible or resistant to trawl disturbance. Methods to identify such areas have already been proposed by Diesing et al. (2013), who estimated the probability that fishing disturbance exceeded natural disturbance by comparing fishing intensity and bed shear stress. They identified areas that are expected to be particularly vulnerable or resilient to bottom fishing on the basis of the bed shear stress in these areas without an understanding of the associated benthic communities. Our results broadly confirm the applicability of their proposed method, even though there will be some complexity of response that reflects local site characteristics.

Trawl disturbance reduced the proportion of 10 modalities of 9 different traits in 3 areas subject to low shear stress. The same type of trait modalities have been observed to decline in previous studies (see Kaiser et al. 2006 for a meta-analysis, Tillin et al. 2006, de Juan et al. 2007, Kenchington et al. 2007). Most of these studies focused on the epifaunal benthic component, while our results clearly reveal that similar effects of bottom trawling may be expected when infaunal data are used. Trawling had most adverse effects on infaunal organisms positioned between 0 and $5 \mathrm{~cm}$ in the seabed, and this may be expected as trawl gears penetrate at least a few $\mathrm{cm}$ into most soft sediments (Eigaard et al. 2015). Species positioned deeper in the sediment and species living
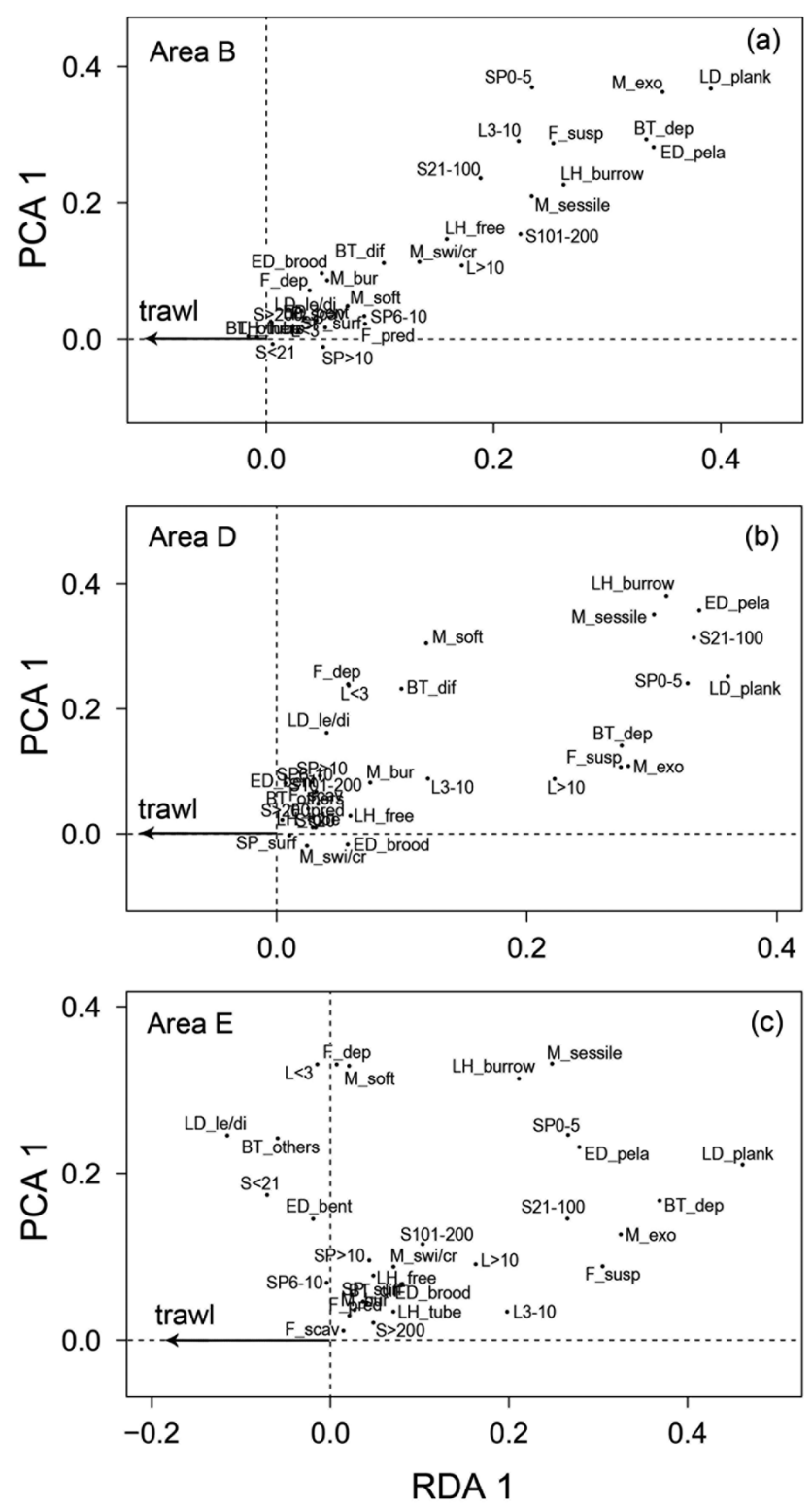

Fig. 5. Outcome of the redundancy analysis for all areas (B, D, E; see Table 1) where trawl disturbance had a significant effect on community composition (all p-values <0.05). Abbreviations correspond to the trait modalities in Table 2

on the seabed surface were less affected by trawling in our study. The latter is unexpected but could be explained by the fact that most surface-living animals in our dataset were mobile swimmers or crawlers, which may repopulate trawled grounds more easily after trawling disturbance (de Juan et al. 2007). The effects of trawling led, in our study, to community compositions comparable with those in areas subject to high natural disturbance, being composed of either small-sized, deposit-feeding animals or mobile scavengers and predators. 
Table 3. Trawl effects on 4 different genera that were not included in the trait-based analysis as their responses overshadow the community response (see Supplement 1). Analysis was done using a linear regression model, genera biomass is $\log (x+1)$ transformed. The regression model for Area $\mathrm{C}$ includes the effects of productivity and percentage silt, which are both significantly related to Echinocardium biomass (not shown). See the Table 1 legend for area codes

\begin{tabular}{|lcrrcc|}
\hline Genera & Area & Intercept & Slope & $\mathrm{R}^{2}$ & $\mathrm{p}$ \\
\hline Brissopsis & $\mathrm{A}$ & 1.07 & 0.32 & 0.08 & 0.17 \\
Echinocardium & $\mathrm{B}$ & 1.48 & -0.52 & 0.08 & 0.48 \\
Echinocardium & $\mathrm{C}$ & -0.06 & 0.04 & 0.09 & 0.31 \\
Echinocardium & $\mathrm{D}$ & 2.45 & -0.26 & 0.48 & 0.003 \\
Amphiura & $\mathrm{D}$ & 2.35 & -0.26 & 0.57 & 0.001 \\
Brissopsis & $\mathrm{E}$ & 2.09 & 0.02 & 0.11 & 0.51 \\
Echinocardium & $\mathrm{H}$ & 0.27 & -0.02 & 0.00 & 0.50 \\
Ensis & $\mathrm{H}$ & 0.14 & 0.00 & 0.01 & 0.92 \\
\hline
\end{tabular}

The clearest indication of changes in community function in response to trawling is the strongly negative association of surface deposition (a modality of bioturbation) with trawl disturbance. This is mainly the result of a decline in suspension-feeding organisms. A decline in the biomass of this functional group means that less organic material is captured in the water column and deposited onto the seabed (Gili \& Coma 1998, Snelgrove 1999, Pearson 2001, Lohrer et al. 2004, Thrush \& Dayton 2010), which potentially reduces benthic secondary production by suspension feeders in the trawled areas.

We detected no effects of trawling in the area characterised by the lowest shear stress (Area A). The community composition of this area, at both low and high trawl disturbance, is most similar to a naturally perturbed community, but differs as many organisms are large-sized and have direct or lecithotrophic larval development. These types of development are often observed in deep areas with limited amounts of planktonic food (Vance 1973). Indeed, Area A is located deepest and has the lowest primary productivity of our study areas. Food limitation has also been observed in the area for one long-living suspension-feeder, Arctica islandica, which had relatively low growth rates (Witbaard et al. 1999). The changes in the benthic community in response to a low benthic production in the area could have interfered with the response of the benthic community to the effect of trawl disturbance.

We sampled the smaller and more abundant epiand infaunal component of the benthic ecosystem. This resulted in a relatively low power to detect the effects of trawling on larger epifauna (species like shrimps, starfish and sea pens). In 2 of the areas where we detected no effects of trawling (A and F), trawl effects have been found on trait composition for larger epifauna sampled using a small beam trawl (Tillin et al. 2006). In these datasets, long-living and suspension-feeding trait modalities were particularly negatively affected by trawl disturbance. Furthermore, we found no effects of trawling in Area C, while trawl effects on benthic species richness have been previously detected in this area (van Denderen et al. 2014). Conversely, we observed fishing effects in Area $B$, whereas no effects of trawling on larger epifauna have been detected in this area (Tillin et al. 2006). These comparisons show that trawling can have differential effects on different components of the benthos, with the result that impacts may be overlooked unless several sampling gears and community indicators (e.g. diversity, biomass and trait composition) are used.

The effects of trawling were examined in all areas over a gradient of commercial bottom trawling intensity. Such a comparative analysis can result in differences in community composition along the trawling gradient that seem to be related to fishing impact, while in fact these patterns result from the fishery selecting areas with a particular community composition where they catch the most fish (see also Tillin et al. 2006). Such effects may be especially relevant at large spatial scales (scales at which the fishery fleet operates), where a large part of the variation in fishing effort can be explained by gradients in environmental conditions (van Denderen et al. 2014). However, others have shown that unfished habitats are not necessarily unsuitable for fishing (Dinmore et al. 2003) and it has been suggested that fisheries often return to areas that are known to be free from obstructions that could damage the gear (Holland \& Sutinen 2000). In addition, Tillin et al. (2006) postulated that trawl effects on benthic communities can have a much larger impact than is expected from small changes in environmental conditions. This is also true for our study areas, where even large differences in silt content of the seabed sediments in Areas $\mathrm{B}$ and E (Table 1) were associated with similar trait compositions (Figs. 2 \& 4).

Since the North and Irish Seas have been trawled for a long time (Brander 1980, de Groot 1984), the sampling stations least exposed to trawl disturbance are unlikely to be in a pristine state. For those areas where there were no detectable effects of trawling, we cannot be certain whether the areas had not recovered from historic trawl disturbance or whether the effects of trawl disturbance were relatively low in relation to natural disturbance. However, it is clear 
from our results that trawl disturbance has a limited additional effect on the benthic ecosystem in areas exposed to high shear stress compared to areas exposed to low shear stress.

In a previous study conducted in Area E, Jennings et al. (2001b) examined whether there was an increase in biomass of some benthic species in response to trawling. In their study, they investigated the benthic infauna as an aggregated group and this approach revealed a lack of a significant positive response to trawl impact. They recommended that future trawl studies should focus on the smallest macrofauna (and meiofauna) as these have sufficiently fast life cycles to benefit from trawl disturbance. These faunal groups were positively correlated with bottom-trawling intensity in our study in Area E, although their increase was not statistically significant when trait modalities were individually analysed (see Supplement 2). The increase was mostly related to a high abundance of polychaetes from the family Scalibregmatidae and, to a lesser extent, the Sipunculidae at the trawled stations. Such an increase may be expected when the species that are relatively less sensitive to trawl disturbance benefit from an increase in available food, due to a decline of their more sensitive competitors (Jennings et al. 2001b, Hiddink et al. 2008, van Denderen et al. 2013).

The biomass of fauna in most of the study areas was dominated by 1 or 2 genera. The responses of these genera to trawling were assessed separately to avoid confounding responses of the community (see Supplement 1). Except for Area D, where the biomass of Amphiura and Echinocardium decreased significantly, none of the dominant genera showed a response, despite their assumed sensitivity to trawl gears (Bergman \& van Santbrink 2000, Callaway et al. 2007). Although individuals are heavy in relation to other fauna, the small sample sizes taken by grabs and cores may not provide a good indication of mean density and thus the power to detect any responses to trawling disturbance will be low. Samples from small beam trawls and dredges that sample larger areas and integrate some of the expected small scale patchiness in the distribution of these genera would likely provide better data for testing whether these genera are affected by trawling disturbance. These genera contain species that are important habitat facilitators, e.g. the brittle star Amphiura filiformis and the heart urchins Brissopsis lyrifera and Echinocardium cordatum (Hollertz \& Duchêne 2001, Lohrer et al. 2004, 2013, van Nes et al. 2007), and these may facilitate other benthos by providing resources and shelter (Thrush et al. 1992, Stachowicz
2001). Effects of trawling on these facilitators may, hence, indirectly affect the benthic component that is the focus of this study.

We conclude that high levels of natural disturbance that affect soft-sediment habitats will lead to community compositions and functions that are more resilient to a given level of trawling disturbance than those found in areas with less natural disturbance. Such asymmetric impacts of bottom fishing will help to identify areas that are particularly susceptible or resilient to trawling and thereby support the development of spatial management plans that deal with the ongoing process of balancing fisheries exploitation and conservation of marine benthic ecosystems.

Acknowledgements. We thank the anonymous reviewers for their helpful suggestions to improve the manuscript and J. Aldridge, N. T. Hintzen and P. Ruardij for their help in assembling the data. This research was partially supported through grants from the policy support research programme (BO) of the Dutch Ministry of Economic Affairs to P.D.vD. and T.vK., the FP7 project BENTHIS (312088) to A.D.R., T.vK and J.G.H., and the Schure Beijerinck Popping Fund of the Royal Netherlands Academy of Arts and Sciences to P.D.vD.

\section{LITERATURE CITED}

Baretta JW, Ebenhöh W, Ruardij P (1995) The European regional seas ecosystem model, a complex marine ecosystem model. Neth J Sea Res 33:233-246

Bergman MJN, van Santbrink JW (2000) Mortality in megafaunal benthic populations caused by trawl fisheries on the Dutch continental shelf in the North Sea in 1994. ICES J Mar Sci 57:1321-1331

Bolam SG, Coggan RC, Eggleton J, Diesing M, Stephens D (2014) Sensitivity of macrobenthic secondary production to trawling in the English sector of the Greater North Sea: A biological trait approach. J Sea Res 85:162-177

Brander K (1980) Fisheries management and conservation in the Irish Sea. Helgol Meeresunters 33:687-699

Bremner J (2008) Species' traits and ecological functioning in marine conservation and management. J Exp Mar Biol Ecol 366:37-47

Bremner J, Frid C, Rogers S (2003) Assessing marine ecosystem health: the long-term effects of fishing on functional biodiversity in North Sea benthos. Aquat Ecosyst Health Manage 6:131-137

Callaway R, Engelhard GH, Dann J, Cotter J, Rumohr H (2007) A century of North Sea epibenthos and trawling: comparison between 1902-1912, 1982-1985 and 2000. Mar Ecol Prog Ser 346:27-43

Chevene F, Doléadec S, Chessel D (1994) A fuzzy coding approach for the analysis of long-term ecological data. Freshw Biol 31:295-309

Collie JS, Hall SJ, Kaiser MJ, Poiner IR (2000a) A quantitative analysis of fishing impacts on shelf-sea benthos. J Anim Ecol 69:785-798

Collie JS, Escanero GA, Valentine PC (2000b) Photographic evaluation of the impacts of bottom fishing on benthic 
epifauna. ICES J Mar Sci 57:987-1001

de Groot SJ (1984) The impact of bottom trawling on benthic fauna of the North Sea. Ocean Manag 9:177-190

de Juan S, Thrush SF, Demestre M (2007) Functional changes as indicators of trawling disturbance on a benthic community located in a fishing ground (NW Mediterranean Sea). Mar Ecol Prog Ser 334:117-129

$>$ Diesing M, Stephens D, Aldridge J (2013) A proposed method for assessing the extent of the seabed significantly affected by demersal fishing in the Greater North Sea. ICES J Mar Sci 70:1085-1096

> Dinmore TA, Duplisea DE, Rackham BD, Maxwell DL, Jennings $S$ (2003) Impact of a large-scale area closure on patterns of fishing disturbance and the consequences for benthic communities. ICES J Mar Sci 60:371-380

Eastwood P, Mills C, Aldridge J, Houghton C, Rogers S (2007) Human activities in UK offshore waters: an assessment of direct, physical pressure on the seabed. ICES J Mar Sci 64:453-463

> Ebenhoh W, Baretta-Bekker JG, Baretta JW (1997) The primary production module in the marine ecosystem model ERSEM II, with emphasis on the light forcing. J Sea Res 38:173-193

Eigaard OR, Bastardie F, Breen M, Dinesen GE and others (2015) Estimating seabed pressure from demersal trawls, seines, and dredges based on gear design and dimensions. ICES J Mar Sci, doi:10.1093/icesjms/fsv099

Eleftheriou A, Moore DC (2005) Macrofauna techniques. In: Eleftheriou A, McIntyre A (eds) Methods for the study of marine benthos, 3rd edn. Blackwell Science, Oxford, p 160-228

FAO (2009) The state of world fisheries and aquaculture 2008 (Sofia). FAO, Rome

Foden J, Rogers SI, Jones AP (2011) Human pressures on UK seabed habitats: a cumulative impact assessment. Mar Ecol Prog Ser 428:33-47

Folk RL (1954) The distinction between grain size and mineral composition in sedimentary-rock nomenclature. J Geol 62:344-359

Gili JM, Coma R (1998) Benthic suspension feeders: their paramount role in littoral marine food webs. Trends Ecol Evol 13:316-321

Hiddink JG, Jennings S, Kaiser MJ, Queiros AM, Duplisea DE, Piet GJ (2006) Cumulative impacts of seabed trawl disturbance on benthic biomass, production, and species richness in different habitats. Can J Fish Aquat Sci 63: 721-736

> Hiddink JG, Rijnsdorp AD, Piet G (2008) Can bottom trawling disturbance increase food production for a commercial fish species? Can J Fish Aquat Sci 65:1393-1401

> Hiddink JG, Johnson AF, Kingham R, Hinz H (2011) Could our fisheries be more productive? Indirect negative effects of bottom trawl fisheries on fish condition. J Appl Ecol 48:1441-1449

- Hinz H, Prieto V, Kaiser MJ (2009) Trawl disturbance on benthic communities: chronic effects and experimental predictions. Ecol Appl 19:761-773

> Holland DS, Sutinen JG (2000) Location choice in New England trawl fisheries: old habits die hard. Land Econ 76:133-149

> Hollertz K, Duchêne JC (2001) Burrowing behaviour and sediment reworking in the heart urchin Brissopsis lyrifera Forbes (Spatangoida). Mar Biol 139:951-957

$>$ Hunt HL, Scheibling RE (1997) Role of early post-settlement mortality in recruitment of benthic marine invertebrates.
Mar Ecol Prog Ser 155:269-301

Jennings S, Kaiser MJ (1998) The effects of fishing on marine ecosystems. Adv Mar Biol 34:201-352

Jennings S, Pinnegar JK, Polunin NVC, Warr KJ (2001a) Impacts of trawling disturbance on the trophic structure of benthic invertebrate communities. Mar Ecol Prog Ser 213:127-142

Jennings S, Dinmore TA, Duplisea DE, Warr KJ, Lancaster JE (2001b) Trawling disturbance can modify benthic production processes. J Anim Ecol 70:459-475

Jennings S, Nicholson MD, Dinmore TA, Lancaster JE (2002) Effects of chronic trawling disturbance on the production of infaunal communities. Mar Ecol Prog Ser 243: 251-260

Johnson AF, Gorelli G, Jenkins SR, Hiddink JG, Hinz H (2015) Effects of bottom trawling on fish foraging and feeding. Proc R Soc B 282:20142336

Kaiser MJ (1998) Significance of bottom-fishing disturbance. Conserv Biol 12:1230-1235

Kaiser MJ, Spencer BE (1996) The effects of beam-trawl disturbance on infaunal communities in different habitats. J Anim Ecol 65:348-358

Kaiser MJ, Collie JS, Hall SJ, Jennings S, Poiner IR (2002) Modification of marine habitats by trawling activities: prognosis and solutions. Fish Fish 3:114-136

Kaiser MJ, Clarke KR, Hinz H, Austen MCV, Somerfield PJ, Karakassis I (2006) Global analysis of response and recovery of benthic biota to fishing. Mar Ecol Prog Ser 311:1-14

Kenchington EL, Kenchington TJ, Henry LA, Fuller S, Gonzalez P (2007) Multi-decadal changes in the megabenthos of the Bay of Fundy: the effects of fishing. J Sea Res 58:220-240

> Lambert GI, Jennings S, Kaiser MJ, Davies TW, Hiddink JG (2014) Quantifying recovery rates and resilience of seabed habitats impacted by bottom fishing. J Appl Ecol 51: 1326-1336

Legendre P, Legendre L (2012) Numerical ecology. Elsevier, Amsterdam

Lohrer AM, Thrush SF, Gibbs MM (2004) Bioturbators enhance ecosystem function through complex biogeochemical interactions. Nature 431:1092-1095

- Lohrer AM, Rodil IF, Townsend M, Chiaroni LD, Hewitt JE, Thrush SF (2013) Biogenic habitat transitions influence facilitation in a marine soft-sediment ecosystem. Ecology 94:136-145

> Morris AW, Howarth MJ (1998) Bed stress induced sediment resuspension (SERE 88/89). Cont Shelf Res 18:1203-1213

Oksanen J, Blanchet FG, Kindt R, Legendre P and others (2013) vegan: community ecology package. R package version 2.0-8. http://CRAN.R-project.org/package=vegan

Pearson TH (2001) Functional group ecology in softsediment marine benthos: the role of bioturbation. Oceanogr Mar Biol Annu Rev 39:233-267

Probert PK (1984) Disturbance, sediment stability, and trophic structure of soft-bottom communities. J Mar Res 42:893-921

Queirós AM, Hiddink JG, Kaiser MJ, Hinz H (2006) Effects of chronic bottom trawling disturbance on benthic biomass, production and size spectra in different habitats. J Exp Mar Biol Ecol 335:91-103

Snelgrove PVR (1999) Getting to the bottom of marine biodiversity: sedimentary habitats: ocean bottoms are the most widespread habitat on Earth and support high biodiversity and key ecosystem services. Bioscience 49: $129-138$ 
Stachowicz JJ (2001) Mutualism, facilitation, and the structure of ecological communities. Bioscience 51:235-246

Suzuki R, Shimodaira H (2006) Pvclust: an R package for assessing the uncertainty in hierarchical clustering. Bioinformatics 22:1540-1542

Thistle D (1981) Natural physical disturbances and communities of marine soft bottoms. Mar Ecol Prog Ser 6:223-228

Thrush SF, Dayton PK (2010) What can ecology contribute to ecosystem-based management? Ann Rev Mar Sci 2: 419-441

Thrush SF, Pridmore RD, Hewitt JE, Cummings VJ (1992) Adult infauna as facilitators of colonization on intertidal sandflats. J Exp Mar Biol Ecol 159:253-265

Tillin HM, Hiddink JG, Jennings S, Kaiser MJ (2006) Chronic bottom trawling alters the functional composition of benthic invertebrate communities on a sea-basin scale. Mar Ecol Prog Ser 318:31-45

Editorial responsibility: Paul Snelgrove,

St. John's, Newfoundland and Labrador, Canada van Denderen PD, van Kooten T, Rijnsdorp AD (2013) When does fishing lead to more fish? Community consequences of bottom trawl fisheries in demersal food webs. Proc R Soc B 280:20131883

> van Denderen PD, Hintzen NT, Rijnsdorp AD, Ruardij P, van Kooten T (2014) Habitat-specific effects of fishing disturbance on benthic species richness in marine soft sediments. Ecosystems 17:1216-1226

van Nes EH, Amaro T, Scheffer M, Duineveld GCA (2007) Possible mechanisms for a marine benthic regime shift in the North Sea. Mar Ecol Prog Ser 330:39-47

Vance RR (1973) On reproductive strategies in marine benthic invertebrates. Am Nat 107:339-352

Witbaard R, Duineveld G, de Wilde P (1999) Geographical differences in growth rates of Arctica islandica (Mollusca: Bivalvia) from the North Sea and adjacent waters. J Mar Biol Assoc UK 79:907-915

Submitted: July 23, 2015; Accepted: November 10, 2015 Proofs received from author(s): December 4, 2015 